\title{
Avanserte MR-metoder for kartlegging av hjernefunksjoner
}

Video til artikkel på www.tidsskriftet.no

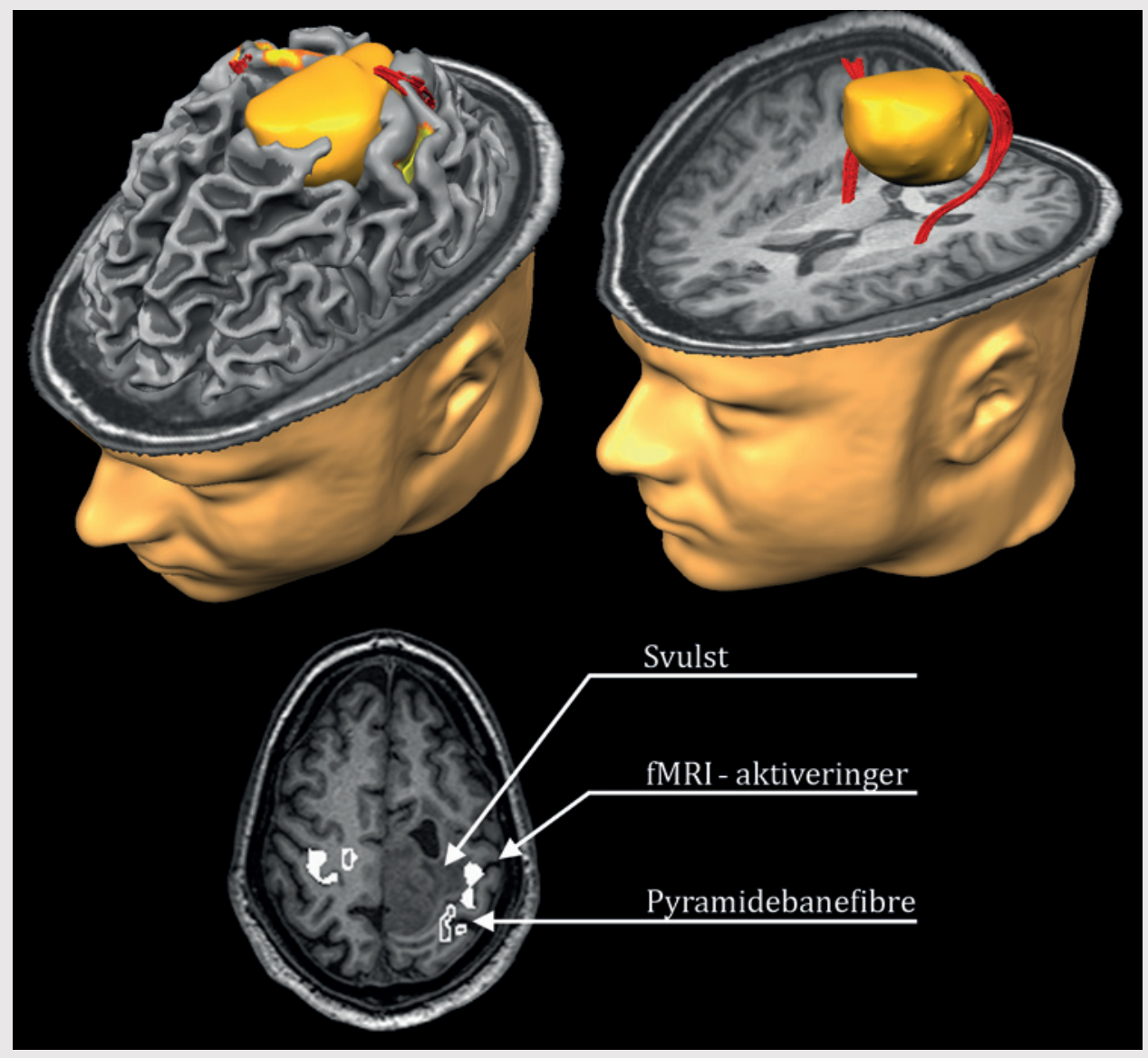

Ved hjelp av avanserte MR-metoder kan man kartlegge viktige områder i hjernens grå og hvite substans som tradisjonelle MRundersøkelser ikke lokaliserer. I eksemplet på figuren er det laget tredimensjonale overflatemodeller av en pasient med en primær hjernesvulst (oransje oppfylning) som involverer de øvre deler av det primære motoriske området $\mathrm{i}$ venstre hemisfære. Ved bruk av funksjonell MR (fMRI) er det primære motoriske området for fingre kartlagt i begge hjernehalvdeler og visualisert som gule/ oransje områder på hjerneoverflaten. Ved bruk av diffusjonstensor-MR (dt-MRI/DTI) er pyramidebanefibrene (tractus corticospinalis), de aksonale banene fra det primære motoriske området til ryggmargen, visualisert som røde fibre. På det nederste bildet er fMRI-aktiveringene og pyramidebanefibrene lagt over på et aksialt $\mathrm{T}_{1}$-vektet MR- bilde av hjernen og svulsten. fMRI-aktiveringene ses som høyintense hvite områder og pyramidebanefibrene som høyintense hvite omriss. I dette eksemplet kan vi se at det primære motoriske området for fingre ligger svært nær svulsten, samtidig som at pyramidebanefibrene er forskjøvet lateralt og posteriort av svulsten. Se video på nett for fullstendig fremstilling.

Disse MR-metodene er implementert som en del av rutinediagnostikken ved bl.a. St. Olavs hospital ved preoperativ kartlegging av hjernesvulster som ligger nær viktige hjerneområder. De anatomiske MRbildene med overlagt fMRI og DTI kan brukes til navigasjon under selve operasjonen ved at denne informasjonen legges inn $\mathrm{i}$ de navigasjonssystemer som benyttes ved slike inngrep.

\section{Erik Magnus Berntsen}

erik.berntsen@stolav.no

Klinikk for bildediagnostikk og Nasjonal kompetansetjeneste for funksjonell MRI St. Olavs hospital

og

Medical Imaging Laboratory (MI Lab) og Institutt for sirkulasjon og bildediagnostikk

Det medisinske fakultet

Norges teknisk-naturvitenskapelige universitet

Erik Magnus Berntsen (f. 1982) er ph.d. og lege i spesialisering i radiologi.

Ingen oppgitte interessekonflikter.

Mottatt 1.2. 2011, første revisjon innsendt 21.4. 2011, godkjent 13.10. 2011. Medisinsk redaktør Siri Lunde. 